\title{
A RESEARCH ON IDENTIFYING THE NEED FOR DISTANCE EDUCATION FOR NATIONAL ATHLETES WHO STUDY IN SCHOOL OF PHYSICAL EDUCATION AND SPORT
}

\begin{abstract}
Taner BOZKUS, PhD
School of Physical Education and Sport Bartın University, Bartın, TURKEY

\section{ABSTRACT}

The purpose of this study was to identify the problems which national athletes, who study in School of Physical Education and Sport in universities, encounter in formal education and to determine their need for distance learning. Qualitative research, which is one the techniques of researching the method of the study, forms a structured deliberation technique. Deliberation questions are prepared with this technique based on expert opinions and during the deliberation, the questions were asked to the people who attended the deliberation in a partially flexible way. Population and sampling of the research; population of the study is the people who study in School of Physical Education and Sports, and sampling is the $\mathbf{3 4 8}$ national athletes who study wrestling, bocce, dart, bowling, basketball, volleyball, football, taekwando, karate, archery, atheism, tennis, judo, badminton, table tennis, boxing, weight lifting, handball, gymnastics and swimming in School of Physical Education and Sports. \%20.4 of these sportsmen are female, \%79.6 of them are male and \%78.7 of them are between 19-25 years old, $\% 14.4$ of them are between 26-30 years old, \%4.3 of them are between 31-35 years old, and \%2.6 of them are 36 years old and older. \%26.4 of the sportsmen who attend the research, study Coaching, \%49.7 of them study Profession of Teaching, \%14.1 of them study Sport Management and \%9.8 of them study Recreation. And \%97.7 of these sportsmen receive undergraduate education, $\% 2.3$ of them receive graduate education.
\end{abstract}

At the end of the study, the national athletes, who attended the research, emphasized that they were having problems in formal education, they failed the exams because they couldn't follow the courses, when they had to attend the courses, they delayed their trainings, and this situation effected their education level. \%87.9 of the national athletes who took part in the study pointed that they need distance learning and if such a programme is developed, they could follow the courses even when they were resting in the camping and they think that a programme like this must be developed as soon as possible.

Keywords: Formal, distance education, national athletes, analysis of need.

\section{INTRODUCTION}

Developments which grow very fast in science and technology in the world in the last century, fast increasing population of the world, increase of the needs of the societies in 
education, but despite these, insufficiency of educational institutions, course materials and teachers, settlement far from the educational institutions, high prices in traditional educations, education requests of the adults who have to go to work, requests for changing department by having a certificate or a diploma or by developing themselves, requests for promotion in the institution, but their obligation to continue courses in educational institutions; such these factors pushed the societies to find new searches in education area.

These searches which are mostly made by developed countries provided the developing of the "distance learning" method (ALKAN 1996).

In line with recently developing technology, distant education systems based on information technologies are started to be commonly used within higher education. Lately, almost all of the universities in our country founded distant education units and started to provide education services by this means. It is possible to evaluate distant education programs and applications based on various parameters. Of these parameters, students' satisfaction is considered among the most important ones. In the broadest terms, students' satisfaction can be defined as the satisfaction and content of students regarding the education services they receive. Factors regarding students' satisfaction are influenced by individual characteristics. Factors affecting students' satisfaction in a distant education/e-learning environment can be divided into six categories which are student, instructor, course, technology, system design and environmental aspects (OZYURT, H. 2014)

Distance learning gives students the opportunity to regulate important study factors such as place, time and pace, depending on their professional, social and personal obligations. It is especially beneficial for adult students to participate in distance learning educational programs (Bebetsos, E. \& GOULIMARIS, D. 2014).

Distance education is used in a variety of settings and for a broad range of purposes. Universities use it to increase the number of students who have access to higher education; companies use it to upgrade their workers' skills and keep them abreast of rapidly advancing technologies; individuals use it for their own professional development and to enhance their career opportunities; governments use it to provide on-the-job training to teachers or other workers, to enhance the quality of traditional primary and secondary schooling, and to deliver instruction to remote rural areas that might not otherwise be served. Various technologies have been used for distance education, but print-based correspondence courses have been, and will continue to be, the dominant delivery mechanism in both the developed and the developing worlds. Print is still the cheapest technology, and, even if the costs of using high-tech dissemination tools fall below those of print, it will be some time before many countries have adequate infrastructures. Higher education; within the university setting, some institutions offer only distance education, while others provide both distance and conventional education.

Those that offer only distance learning is referred to as "open universities," and most are modeled after the United Kingdom's Open University. Mega-universities are large open universities, each of which enrolls more than 100,000 students per year; combined enrollment is some 2.8 million. (http://tojde.anadolu.edu.tr/fdmarchnws.htm) 
2008-2009 education-teaching period, distance education became more common in undergraduate education with the new programmes which universities started. At the present day, universities continue their studies on distance education with two-year degree education, undergraduate education and graduate education programmes. (Arar, 1999)

\section{METHOD}

In the research, the purpose is to analyze national athlete's need for distance learning, who studies in formal education programmes in School of Physical Education and Sport at universities. Population and sampling of the research; population of the study is the people who study in School of Physical Education and Sports, and sampling is the $\mathbf{3 4 8}$ national athletes who study wrestling, bocce, dart, bowling, basketball, volleyball, football, taekwando, karate, archery, track \& field, tennis, judo, badminton, table tennis, boxing, weight lifting, handball, gymnastics and swimming in School of Physical Education and Sports.

$\% 20.4$ of these sportsmen are female, \%79.6 of them are male and \%78.7 of them are between 19-25 years old, \%14.4 of them are between $26-30$ years old, $\% 4.3$ of them are between 31-35 years old, and \%2.6 of them are 36 years old and older.

\%26.4 of the sportsmen who attend the research, study Coaching, \%49.7 of them study Profession of Teaching, \%14.1 of them study Sport Management and \%9.8 of them study Recreation. And \%97.7 of these sportsmen receive undergraduate education, $\% 2.3$ of them receive graduate education.

As data gaining process, open-ended questions, which were asked to 348 sportsmen who volunteered to take part in the research, were used.

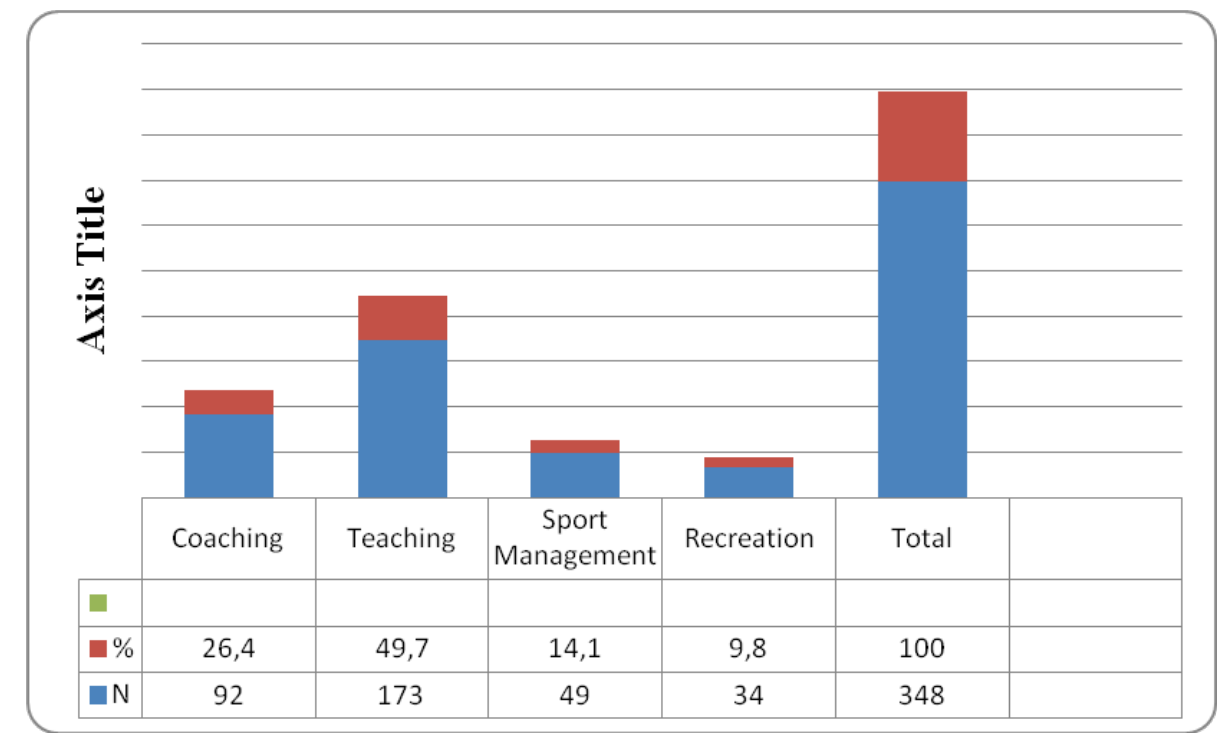

Graphic: 1

The frequency and percentage of participants 


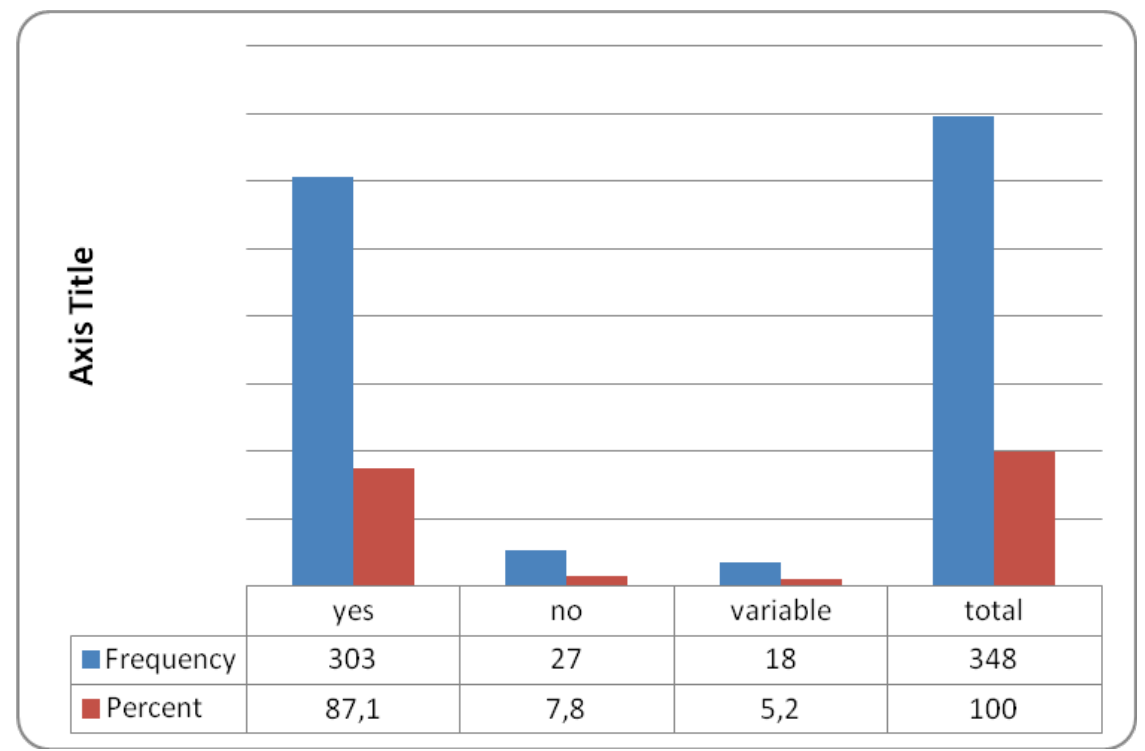

Graphic: 2

The answers of the participants to the question about

\%87 of the sportsmen said "yes", \%7.8 of them said "no" to this question, \%5.2 of them stated that they were variable and generally they expressed that they had failed the exams because of the fact that they couldn't dominate the subjects which are taught during the course, they couldn't follow the curriculum because they couldn't attend the courses and this leads them to break away from the subjects and school environment.

Besides, in some cases, the sportsmen emphasized that they took examination without attending the courses in no account and this affected them seriously.

About this subject, a athlete said that:

"Of course I'm having failure. I can't adjust myself with the curriculum. And this causes me to fall behind in subjects. So, because $i$ fall behind in subjects, $i$ have to take make-up examination. And studying fot make-up examinations causes me not be able to train".

Another athlete answered to this same question as:

"Yes, i can't understand the courses because $i$ can hardly attend the courses and because Another athlete:

I can't put emphasis on the courses, I generally fail."

" Yes, because $i$ can't attend the courses, i fail every exam which are about the subjects which i don't know. 
Q2. When You Attend To National Team Campings, Do You Fail The Courses Because Of Absence?

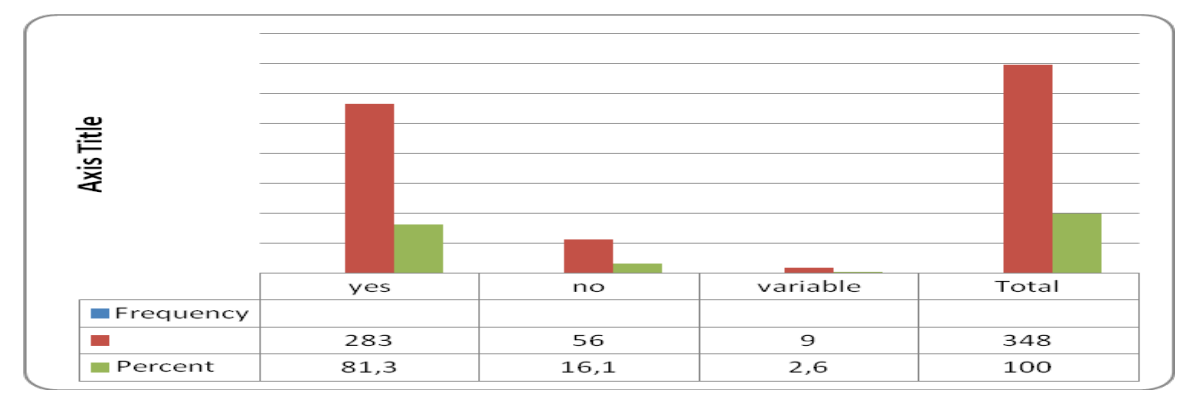

Graphic: 3

The answers of the participants to the question about

\%81.3 of the sportsmen said "yes", \%16.1 of them said "no" to this question, \%5.2 of them stated that they were variable. They expressed that generally they attend to the campings, so they are having failure in courses and when they don't bring a permission slip from the federation, they fail the course. And sometimes the permission is not enough and again they fail the course because of absence.

About this question, a athlete:

"Yes, when we attend the camping, we are listed as absent in the course and fail. And we are listed absent also in the courses which we take from the previous year, so there is an aggregation which causes us to delay graduating".

Generally, the answers are like this. But, a athlete:

" There's no problem if the course has no obligation for attendance, but in the courses which have attendance obligation i simply get a permission slip and recover the situation and I can pass the courses".

Q3. Does It Affect Your Performance in Your Branch When

You Fail The Course Because Of The Fact That You Have To Attend The Campings?

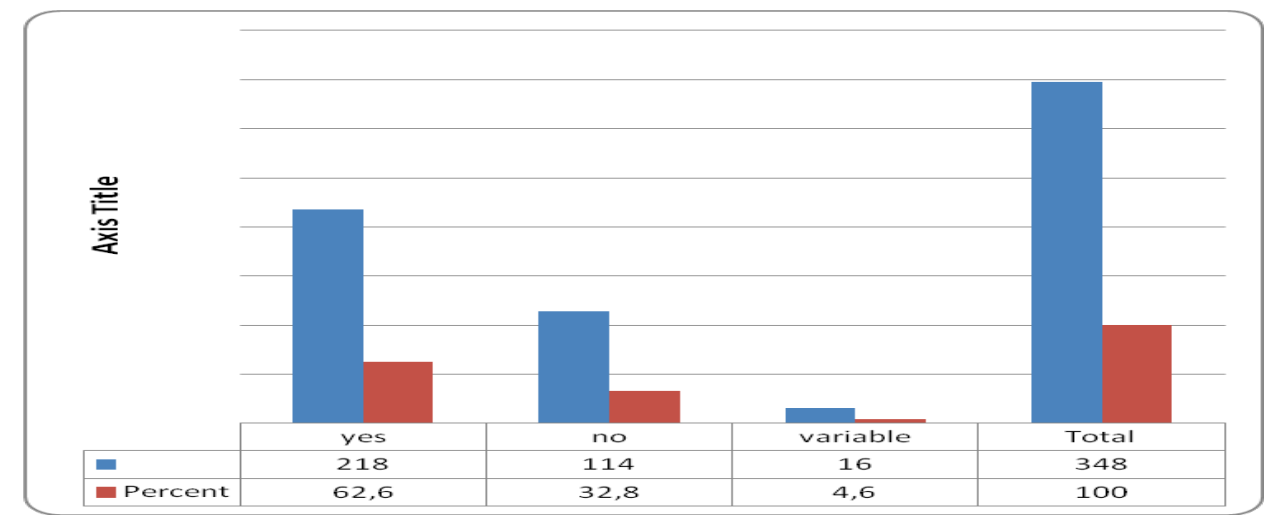

Graphic: 4

The answers of the participants to the question about 
\%62.6 of the sportsmen who took part in the research said "yes", \%32.8 of them said "no" to this question, \%16 of them stated that they were variable.

And the answers are mostly about their studying times' being very short and this doesn't bring them the success and therefore this failure has an effect on their performance.

They expressed that they have to choose one of two options: They have to continue to the school and focus on all the courses or increase their performance by continuing the trainings. They say that they can't do the both, and they are suffering about this situation.

And one of the sportsmen explained it like this:

"Yes, failure at school quite affects the performance. The probability of graduating later than expected causes psychological depression. And this inevitably leads us to focus on school and hinder our trainings, which causes performance decrease."

Another athlete:

"No, my failure at school doesn't affect my performance; I don't let this situation affect me. Of course thinking about graduating later than expected makes me sad, but I amm trying not to think about it, and not to carry this over.

Q4. Your obligation to attend the courses which have obligation of attendance affects your performance?

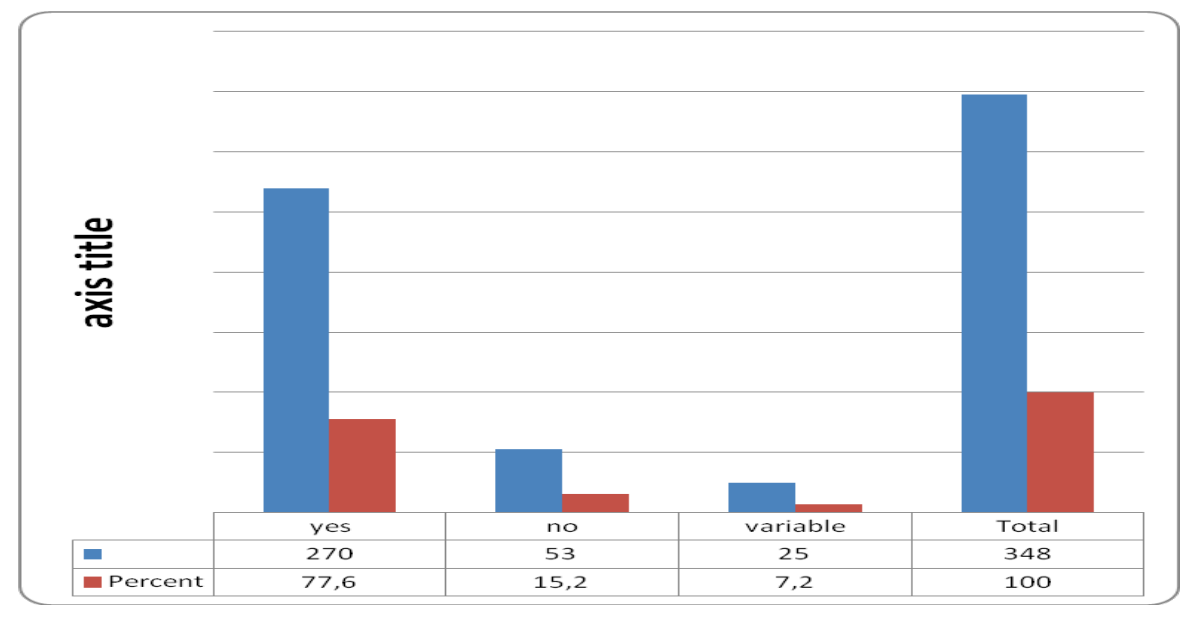

Graphic: 5

The answers of the participants to the question about

\%77.6 of the sportsmen said "yes", \%15.2 of them said "no" to this question, $\% 7.2$ of them stated that they were variable. National athletes answered to this question generally like they have to continue the school and this divides their day, they can' training and even they can completely break away from sport because of the reason that their location being very far from their clubs. 
And of course this situation makes them very sad. About this subject, another athlete:

" Yes, we are having lack of performance. When we are at school, we can't train, and after school, because our day is divided, we get tired and can't do a top-level training and this affects the performance in a negative way.

Another athlete pointed out his opinions about this subject saying:

"Yes, national athletes need a definite programme and is a subject which needs a disciplined developing. But, our present education system doesn't allow this discipline. This obligation in the system affects many of us in a negative way.

\section{Q5. Do you need distance education in the department which you study? Why?}

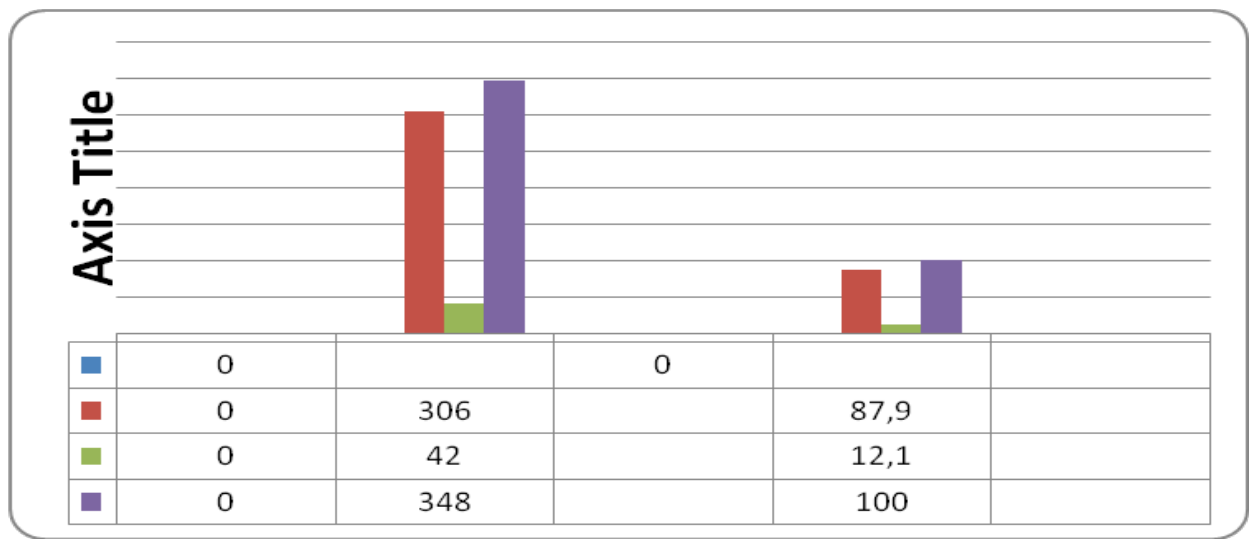

Graphic: 6

The answers of the participants to the question about

\%87.9 of the researchers said "yes", \%12.1 of them said "no" to this question. General thoughts of the sportsmen about this subject are that distance education can be very efficient, and both school success and performance level can be affected by this system in a positive way.

They expressed that they could follow the subjects even during the intervals in the camping and thus they can graduate more efficient and educated which leads sport to develop in our country.

Furthermore, they pointed out that they will have the possibility of training anywhere in any condition without being separated from their clubs.

About this subject, a few of the sportsmen said that:

"Yes, distance education is a need for national athletes. I think that distance education will be an important education model of athlete's being more active and sparing the time for sport. But, this education model must be arranged according to athlete's nationality statute and success and should not hold him back from his training. In this connection, $i$ think that the athlete will have more efficient results both in his educational life and sport life." 
Another athlete pointed out his opinions about this subject saying:

"Yes, absolutely, if our department had a distance education programme, we could be successful both in our sport life and education life. We have many spare times during the campings, so during these spare times we can follow the courses and can have successful results from the exams. Our minds would be relaxed then. We can graduate without fearing about failing. And we can focus our performance only to one way. I definitely think that distance education will be a very useful programme for us national athletes."

Another athlete said that:

"Yes, distance education can be very important for us sportsmen, because we always hold back from the subjects and we fail many courses because of absence problem. If this system is put on practice, there won't be an absence problem and we can study anytime we want. I think this system must necessarily be put on practice."

Another athlete said that:

"Yes We follow both the trainings and the courses more regularly. We don't try to do them both at the same time. During day time we focus on our trainings and during intervals we can focus on our courses. Therefore,

RESULT we can be more successful. I think distance education is an obligatory. "

In this research, which is aimed to determine national athletes' need for distance education, their problems which they face in formal education also were discussed. According to the diagnosis, we can say that sportsmen are having absence problem at schools. And it's determined that, those who don't have this problem, fail their exams because of the fact that they don't attend the courses and have lack of subject learning. This situation also affects national athlete students' sportive performances in a negative way; the absence problem leads the student to the failure both at school and in competitions. As a result of this research, the need for preparing distance education programmes in graduate programmes have come up for the national athlete students, who study in School of Physical Education And Sport, to continue their education in a more sufficient way, to improve their sportive performance on top level, to represent our country with success on the international stage.

\section{BIODATA and CONTACT ADDRESS OF THE AUTHOR}

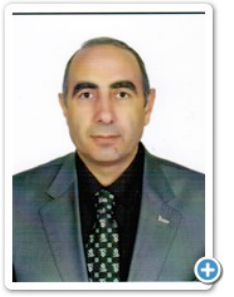

Taner BOZKUS (PhD) is a full time assistant professor lecturing at School of Physical Education and Sport in Bartın University, Turkey. He received his undergraduate degree from Faculty of Sport Sciences in Gazi University, Ankara. Afterwards he continued to his graduate studies in the same university, and received PhD in 2010 . He had worked as a research assistant in the School of Physical Education and Sport in Kırıkkale University from 1999 until 2010, and after then as a lecturer in Bartın University. Now he is also heading the Sport Management Department in the same university. Professionally, he is focused on practical and theoretical studies and applications of Turkish folk dances. 
Bartın University

School of Physical Education and Sport, Bartın, TURKEY

Phone: +90 5054569090

Fax: +903123198909

Email: tanerbozkus@yahoo.com

\section{REFERENCES}

Alkan, C. (12-15 November 1996). Historical Development of Distance Education, presented paper in the First Symposium of International Distance Education in Turkey. Ankara.

Arar, A. (1999). Historical Development of Distance Education, Application Models and Prices of Distance Education, Second Distance Education Symposium, Ankara.

Bebetos, E., Goulimaris, D. (2014). Personal Outcome And Leadership As Defining Factors Of Satisfaction In The Context of The Course Arts II: Overview of Greek Music and Dance of the Hellenic Open University, Turkish Online Journal of Distance Education-TOJDE, April, ISSN 1302-6488 Vol: 15 Number: 2 Article 1.

Daugherty, M. \& Funke, B. L. (1998). University Faculty And Student Perceptions of WebBased Instruction, Journal of Distance Education, 13(1), 21-39.

Ozyurt, H., (2014). Satisfaction Clustering Analysis Of Distance Education Computer Programming Students: A Sample of Karadeniz Technical University, Turkish Online Journal of Distance Education-TOJDE, April, ISSN 1302-6488 Vol: 15 Number: 2 Article 4.

Pyle, R. C. and CHARLES D. D., (2001). Technology: Servant or Master Of The Online Teacher?, Library Trends, 50 (1): 130-144.

Ruksauk, N. (1999). Library and Information Science Distance Education in Thailand in the Next Decade, presented paper 65th IFLA Council and General Conference August 2028 1999, Bangkok, (p.11).

http://tojde.anadolu.edu.tr/fdmarchnws.htm (08/05/2014 11:45 